\title{
Antidiabetic Activities of Muntingia calabura L. Leaves Water Extract in Type 2 Diabetes Mellitus Animal Models
}

\author{
Widhya Aligita*, Elis Susilawati, Ika Kurnia Sukmawati, Lusi Holidayanti, Jejen Riswanti \\ Department of Pharmacology, Bandung School of Pharmacy, Jl. Soekarno Hatta No.754, Bandung, Indonesia \\ *Corresponding author. E-mail: widhya.aligita@stfb.ac.id
}

Received date: Nov 13, 2017; Revised date: Apr 27, 2018; Accepted date: May 3, 2018

\section{Abstract}

B

ACKGROUND: Diabetes mellitus (DM) is a heterogeneous group of disorders characterized by increasing blood glucose levels caused by insufficiency of insulin hormone production and activities. There are significant increases in DM case every year in Indonesia, as a consequent, alternative and better drug is needed to be developed. One of the plants that were often used as traditional medicine for DM in Indonesia was Muntingia carabula L. (kersen) leaf. The aim of this research was to evaluate the antidiabetes activity of $M$. carabula leaves.

METHODS: This study was conducted in vivo by evaluating the antidiabetic activity of $M$. carabula leaf water extract on two animal models, those are insulin deficiency and insulin resistant model animal. The insulin deficiency animal model was developed by aloxan administration at dose of $50 \mathrm{mg} / \mathrm{Kg}$ body weight (bw) intravenously. While the insulin resistance animal model was developed by lipid emulsion administration at dose of $0.42 \mathrm{~mL} / 20$ grams bw orally. Both groups were randomly devided into 6 groups, which are negative control group, positive control group, standard drug group (glybenclamide $0.65 \mathrm{mg} / \mathrm{Kg}$ bw or

\section{Introduction}

Diabetes mellitus (DM) is a group of symptoms that arise due to an increase in blood glucose levels caused by decreasing in insulin secretion progressively.(1) These can be caused by decreasing in insulin secretion, decreasing metformin $135 \mathrm{mg} / \mathrm{Kg} \mathrm{bw}$ ), and extract groups at dose of 100,200 and $400 \mathrm{mg} / \mathrm{Kg}$ bw. Parameters which were evaluated are fasting blood glucose (FBG) levels for insulin deficiency models and values of constant of insulin tolerance $\left(\mathrm{K}_{\mathrm{ITT}}\right)$ for insulin resistant models.

RESULTS: In insulin deficient model group, administration of glibenclamide lower the FBG by $43 \%$, furthermore, the extract of M. calabura at doses of 100,200 and $400 \mathrm{mg} / \mathrm{Kg}$ bw also lower the FBG by $13 \%$, $22 \%$ and $29 \%$, subsequently. In insulin resistant models, metformin increased the value of $\mathrm{K}_{\mathrm{ITT}}$ from less than 0.5 to 2.91, and administration of the extract at doses of 400, 200 and $100 \mathrm{mg} / \mathrm{Kg}$ bw also increased the $\mathrm{K}_{\text {ITT }}$ value to 2.31 , $1.57,1.13$, respectively.

CONCLUSION: The conclusion was $M$. carabula leaves water extract with dose of $400 \mathrm{mg} / \mathrm{Kg}$ bw had the antidiabetic activities with mechanisms to lower blood glucose level, regenerate pancreatic $\beta$ cells, and increase insulin sensitivity.

KEYWORDS: diabetes mellitus, kersen leaves, Muntingia calabura L., insulin deficiency, insulin resistance

Indones Biomed J. 2018; 10(2): 165-70 in insulin sensitivity, or both.(2) The decreasing in insulin sensitivity or what is known as the insulin resistance is a condition when the target cell's ability to respond to insulin decreases. Thus recognized with hiperinsulinemia.(3) The prevalence of DM in Southeast Asia in 2014 was 8.3\%, with undiagnosed cases of 52.8\%.(4) Based on Indonesian Basic Health Research (RISKESDAS) data in 2007, the 
prevalence of DM in Indonesia was as much as 5.7\%.(5) Meanwhile, according to RISKESDAS data in 2013, the prevalence of DM in Indonesian population increased by $6.8 \%$. These data shows that DM has become a disease whose number of sufferers increasing within years.(6)

Type 2 DM (T2DM) is caused by various factors, including genetic and environmental factors. Genetic factors are associated with the ability of the pancreas to secrete insulin, while environmental factors are associated with obesity, overeating, lack of exercise, and stress, as well as aging. Impaired insulin secretion is a decreased ability of $\beta$ cells in responding the glucose in the blood. This particular condition appears long before a T2DM development. Impaired insulin secretion is a progressive condition, and is strongly influenced by glucotoxicity and lipotoxicity. If not treated properly, it will cause mass destruction of pancreatic $\beta$ cells. Insulin resistance is a condition which the insulin is not sufficiently produced proportionally in comparison with its blood concentration ratio. This is due to the insulin receptors impairment located in the liver and muscles.(7)

Diabetics usually require regular monitoring to ensure that blood glucose levels remain in range of blood glucose target and minimize the occurrence of complications. Diet and physical activity are an important factor in managing DM, especially T2DM. In addition to lifestyle regulation, the oral antidiabetic drugs are also often used. Oral diabetes drugs consist of alpha-glucosidase inhibitors, biguanides, meglitinides, sulfonylureas, thiazolidinediones, and dipeptidyl peptidase 4 (DPP-4) inhibitors, a new group of oral antidiabetes.(8)

Treatment of DM until now is still symptomatic and should be done for a lifetime, thus potentially causing various side effects, such as hypoglycemic, headache, vomit, emesis, and symptoms in gastrointestinal. $(9,10)$ Therefore it is necessary to explore the alternative treatment which can stabilize blood glucose level in normal range. Currently, plant is considered as a potential source of bioactive compounds. The secondary metabolite content in the plant has been known to have some activity.

Muntingia calabura L., locally known as kersen, traditionally has been used to control blood glucose level. Based on previous research, M. calabura leaves was known to contain flavonoid compounds, tannins, triterpenoids, saponins, and polyphenols that showed antioxidant activity.(11) Antioxidants are substances that can inhibit or prevent damage or destruction due to oxidation.(12) Oxidative stress plays an important role in causing cell damage due to hyperglycemia. High blood glucose levels can stimulate the formation of free radicals.(13) Free radicals are compounds that have one or more unpaired electrons normally produced in cellular metabolism.(14,15) Oxidative stress occurs due to an imbalance between the number of free radical molecules and antioxidant compounds in the body. Oxidative stress can interfere with the cell's physiological processes, one of which is the islet cells in the pancreas as an insulin-secreting organ. This is because pancreatic islet cells have the least endogenous antioxidant levels compared to other cells.(13) From previous experiment, it was known that $M$. calabura leaves water extract showed the antioxidant activity with total phenolic compound $2970.4 \mathrm{mg} / 100$ grams galic acid.(11) According to this study, M. calabura leaves water extract was assumed to have potential antidiabetes effect. $M$. calabura leaves had also been shown to have antihyperglycemic activity in insulin deficiency animal model.(16) The aim of this research was to evaluate the activity of $M$. calabura leaves as an antidiabetes using two animal model, that was insulin deficiency and insulin resistance animal model.

\section{Methods}

\section{Identification and Authentication of Plant Material}

M. calabura leaves was obtained from Bumi Herbal, Bandung, Indonesia. Fresh plants were dried at $60-70^{\circ} \mathrm{C}$ and then grinded into small pieces. The plant identification and authentication was performed by Biological Department, Padjajaran University, Bandung, Indonesia.

\section{Preparation of M. carabula Leaves Water Extract}

$1 \mathrm{Kg}$ dried leaves of $M$. calabura was infused with $10 \mathrm{~L}$ aquades. The mixture was filtered using a filter paper and the filtrate was concentrated using freeze drier.(17)

\section{Animals}

Male Swiss-Webster mice 2-3 months old weighing 2030 grams were kept at standard laboratory conditions at $24-26^{\circ} \mathrm{C}$, humidity $70-75 \%$, and 12 hours light/dark cycle. Animals were fed with standard chow and water ad libitum. The methods in this study were performed in accordance with ethics and guide for animals care and used. Ethical approval was published by the Ethics Committee Padjajaran University with registration number 0218030380 . The parameter measured in this experiment was fasting blood glucose level and histology of pancreas for insulin deficiency animal model and the value of constant of insulin tolerance test $\left(\mathrm{K}_{\mathrm{ITT}}\right)$ for insulin resistance animal model. 
In vivo Antidiabetic Evaluation of $M$. calabura Leaves Extract in Insulin Deficiency Animal Model

There were two stages in antidiabetic testing in vivo, the first one was the induction phase and the second was the treatment phase. In the first phase, mice were induced with alloxan $50 \mathrm{mg} / \mathrm{Kg}$ body weight (bw) intravenously.(18) Mice with hyperglycemia (blood glucose $>200 \mathrm{mg} / \mathrm{dL}$ ) will be used in the second phase of evaluation. Mice with hyperglycemia were randomly divided into 5 groups, which are positive control group, standard drug group (glybenclamide 0.65 $\mathrm{mg} / \mathrm{Kg} \mathrm{bw}$ ), and extract groups at dose of 100, 200 and 400 $\mathrm{mg} / \mathrm{Kg}$ bw, and the normal mice as a control negative group. Administration of extracts and glybenclamide as a standard drug were performed for 14 days. Parameters measured were blood glucose levels on days 3, 7, 11 and 14 during treatment. Mice blood was taken from the vein part of the tail and measured using EasyTouch ${ }^{\circledR}$ glucometer (Bioptik Technology, Miaoli, Taiwan). On the last day of evaluation, 2 mice from each group were randomly selected to be sacrificed and pancreatic organ isolation was performed for histologic observation. The histologic examination was read by the researcher by comparing the gaps and size of Langerhans islet of each group qualitatively. The data obtained were then analyzed statistically using ANOVA method.

\section{In vivo Antidiabetic Evaluation of $M$. calabura Leaves Extract in Insulin Resistance Animal Model}

There were two stages in antidiabetic testing in vivo, the first one was the induction phase and the second was the treatment phase. In the first phase, mice were induced using lipid emulsion as written in the literature (19) with a modification at dose of $0.42 \mathrm{~mL} / 20$ grams bw for 2 weeks. After mice developed to insulin resistance condition, the experiment stepped to the second phase of evaluation. Mice with insulin resistance were randomly grouped into 5 groups, which are positive control group, standard drug group (metformin $135 \mathrm{mg} / \mathrm{Kg} \mathrm{bw}$ ), and extract groups at dose of 100, 200 and $400 \mathrm{mg} / \mathrm{Kg}$ bw. Administration of extracts and metformin as a standard drug were performed for 14 days. Parameters measured were insulin sensitivity before induction, after induction and after treatment using value of $\mathrm{K}_{\mathrm{ITT}}$. The data obtained were then analyzed statistically using ANOVA method.

\section{Insulin Tolerance Test}

An insulin tolerance test (ITT) was performed using insulin $0.75 \mathrm{U} / \mathrm{Kg}$ bw, intraperitoneally. Blood glucose concentration from the tail vein was measured using the
Easy Touch ${ }^{\circledR}$ blood glucosemeter at 0, 15, 30, 45 and 60 minutes after insulin administration.(20) The data was made into graphical form and the gradient was calculated to obtain the value of $\mathrm{K}_{\text {ITT }}$

\section{Results}

Figure 1 showed that intravenous administration of alloxan caused elevated blood glucose levels in mice $(>200$ $\mathrm{mg} / \mathrm{dL})$. The negative control group had the relatively constant blood glucose level compared to the alloxaninduced group.

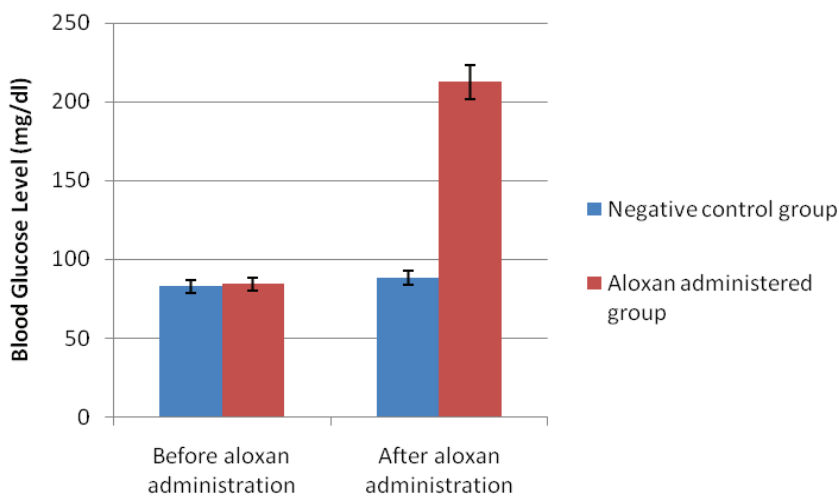

Figure 1. The elevation of blood glucose level upon aloxan administration. $\mathrm{n}$ for the negative control $=5$ mice, $\mathrm{n}$ for the alloxan administered group $=25$ mice.

\section{Effects on Insulin Deficient Model}

Table 1 and Figure 2 showed that all the treated group, either with glybenclamide as a standard drug or with $M$. calabura leaves extract, showed significant improvement in blood glucose level, compared with the positive control group. The glibenclamide group as a standard drug showed the largest decrease in fasting blood glucose level compared to the extract groups.

Table 1. The percentage change in blood glucose level during treatment.

\begin{tabular}{|c|c|c|c|c|}
\hline \multirow[t]{2}{*}{ Group } & \multicolumn{4}{|c|}{$\begin{array}{c}\text { Blood Glucose Level Changes } \\
\text { at Day- }(\%)\end{array}$} \\
\hline & 3 & 7 & 10 & 14 \\
\hline Negative control & $2 \pm 9$ & $-4 \pm 10$ & $-2 \pm 7$ & $-2 \pm 11$ \\
\hline Positive control & $4 \pm 5$ & $5 \pm 7$ & $7 \pm 7$ & $10 \pm 7$ \\
\hline Glibenclamide $0.65 \mathrm{mg} / \mathrm{kg}$ bw & $-8 \pm 2$ & $-20 \pm 6$ & $-34 \pm 6$ & $-43 \pm 7$ \\
\hline Kersen leaves extract $100 \mathrm{mg} / \mathrm{kg}$ bw & $-2 \pm 1$ & $-6 \pm 3$ & $-10 \pm 6$ & $-13 \pm 9$ \\
\hline Kersen leaves extract $200 \mathrm{mg} / \mathrm{kg}$ bw & $-3 \pm 2$ & $-10 \pm 4$ & $-18 \pm 8$ & $-22 \pm 7$ \\
\hline Kersen leaves extract $400 \mathrm{mg} / \mathrm{kg}$ bw & $-3 \pm 2$ & $-12 \pm 3$ & $-22 \pm 5$ & $-29 \pm 4$ \\
\hline
\end{tabular}




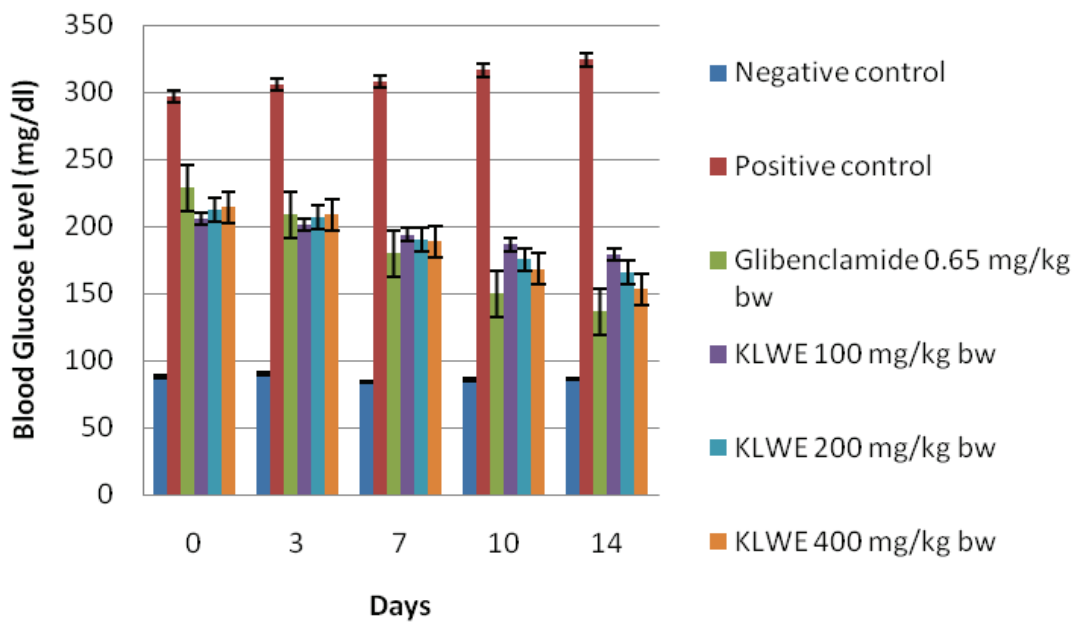

Figure 2. The blood glucose level during treatment. KLWE=Kersen leaves water extract, $p<0.05, \mathrm{n}=5 \mathrm{mice} /$ group.

From Table 1, we could see that the percentage decrease in blood glucose levels in the group given the extract was parallel to the administered dose. The higher the dose, the percentage decrease in blood glucose levels produced even greater. At the end of the experiment, blood glucose levels of glybenclamide group and extracts at dose of 100, 200 and $400 \mathrm{mg} / \mathrm{Kg}$ bw group had not reached normal levels yet. Although all of the dosage groups of extracts had a statistically significant decrease in blood glucose levels compared with positive controls, but only doses of $400 \mathrm{mg} /$ $\mathrm{Kg}$ bw showed similar activity to the glybenclamide group. On the last day of the experiment, the mice were randomly sacrificed and pancreatic isolation was performed for histology with Hematoxylin-Eosin (HE) staining. Histology result was shown in Figure 3.

\section{Effects on Insulin Resistant Model}

Insulin resistant animal models was developed by administrating lipid emulsion (Lipofundin ${ }^{\circledR}$ ) with a dose

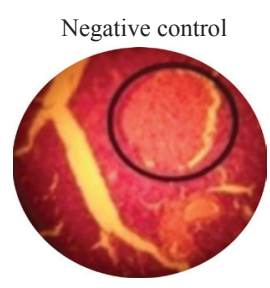

Kersen Leaves Extract $100 \mathrm{mg} / \mathrm{kg}$ bw
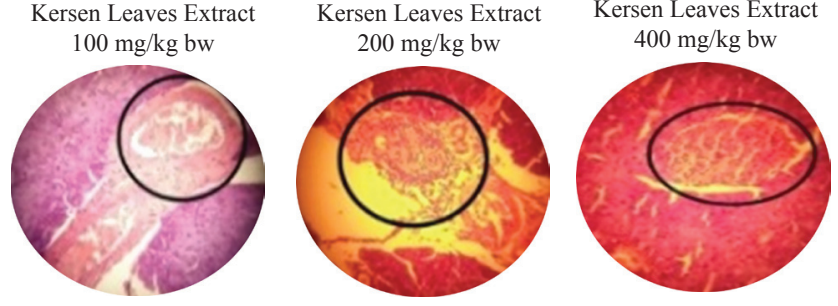

Figure 3. Histology of pancreas with HE staining. The circled area showed Langerhans islet. of $0.42 \mathrm{~mL} / 20$ grams bw. Parameters measured were the value of $\mathrm{K}_{\mathrm{ITT}}$ at the time before induction, after induction, and after treatment. The value of $\mathrm{K}_{\mathrm{ITT}}$ was shown in Table 2.

\section{Discussion}

In vivo Antidiabetic Evaluation of $M$. calabura Leaves Extract in Insulin Deficiency Animal Model

Figure 1 showed that intravenous administration of alloxan caused elevated blood glucose levels in mice (>200 mg/ $\mathrm{dL}$ ). Alloxan is a derivate urea compound that causes hyperglycemia conditions by selectively destroying pancreatic $\beta$ cells that produce insulin. The severity of pancreatic $\beta$ cell damage is determined by the administered alloxan dose.(21). The alloxan toxic mechanism against pancreatic $\beta$ cells is by oxidizing sulphydryl groups, inhibiting glucokinase enzymes, producing free radicals, and disrupting intracellular calcium homeostasis. $(22,23,24)$ The selectivity of alloxan to pancreatic $\beta$ cells is due to the similarity of structures with glucose which resulted in the mechanism of alloxan uptake by pancreatic $\beta$ cells to be highly efficient.(25)

Standard drug administration and extracts were performed for 14 days in hyperglycemic animals. Blood glucose levels as a parameter were measured at days 3, 7, 10 and 14 treatment. Figure 2 showed that all the treated group, either with glybenclamide as a standard drug or with M. calabura leaves extract, showed significant improvement in blood glucose level compared to positive control group. It was proved by the statistically differences of blood glucose level between the treated group (glybenclamide and extract administered groups) and positive control group at day $3,7,10$, and 14 during treatment. The glybenclamide, as a standard drug, group showed the highest percentage 
Table 2. The value of $K_{\text {ITT }}$ during experiment.

\begin{tabular}{lccc}
\hline \multicolumn{1}{c}{ Group } & $\begin{array}{c}\text { Before } \\
\text { Induction }\end{array}$ & $\begin{array}{c}\text { After } \\
\text { Induction }\end{array}$ & $\begin{array}{c}\text { 14 Days After } \\
\text { Treatment }\end{array}$ \\
\hline Negative control & $1.41 \pm 0.78$ & $2.20 \pm 1.70^{*}$ & $2.00 \pm 0.56^{*}$ \\
Positive control & $1.83 \pm 0.33$ & $0.18 \pm 0.20$ & $0.25 \pm 0.15^{\#}$ \\
Metformin $135 \mathrm{mg} / \mathrm{kg} \mathrm{bw}$ & $1.61 \pm 0.48$ & $0.21 \pm 0.33$ & $2.91 \pm 1.15^{*}$ \\
Kersen leaves extract $100 \mathrm{mg} / \mathrm{kg} \mathrm{bw}$ & $1.75 \pm 0.87$ & $0.20 \pm 0.60$ & $1.13 \pm 0.60^{\#}$ \\
Kersen leaves extract $200 \mathrm{mg} / \mathrm{kg} \mathrm{bw}$ & $2.00 \pm 0.56$ & $0.09 \pm 0.14$ & $1.57 \pm 0.71^{*}$ \\
Kersen leaves extract $400 \mathrm{mg} / \mathrm{kg} \mathrm{bw}$ & $1.48 \pm 0.51$ & $0.14 \pm 0.18$ & $2.31 \pm 1.21^{*}$ \\
\hline
\end{tabular}

of decreased blood glucose levels compared to the other groups. The changes of blood glucose level during treatment compared to blood glucose level before treatment was presented as a percentage in Table 1. Glybenclamide has the ability to lower blood glucose levels by stimulating insulin secretion by pancreatic $\beta$ cells.(8) Statistically, blood glucose level of all the extract groups at day 3, 7 and 10 showed no significant difference compared to glibenclamide group; whereas at day 14, only the extract group at dose of $200 \mathrm{mg} / \mathrm{dL}$ and $400 \mathrm{mg} / \mathrm{dL}$ showed no significant difference compared to glibenclamide group. It means that the extract at dose of $200 \mathrm{mg} / \mathrm{dL}$ and $400 \mathrm{mg} / \mathrm{dL}$ had the comparable activity with the glibenclamide as a standard drug.

On the last day of the experiment, the mice were sacrificed and pancreatic isolation was performed for histology with HE staining. HE staining allowed for qualitative observation of Langerhans islet. According to Figure 3, there was a significant difference between the Langerhan islet of the positive controls compared with the negative controls. On the negative control, the Langerhans islet looked full and there was no gap, whereas in the positive control group looked not full and there were many loopholes. This indicates the presence of pancreatic damage in animal-induced alloxan and animal modeling of insulin deficiency successfully performed.

While in the glybenclamide and extract group, the Langerhans islet looked fuller although there were still empty gaps. This indicated an improvement on the Langerhans islet due to treatment. Based on histological results, $M$. calabura leaves extract was thought to have the ability to prevent the disruption of Langerhan islet cells due to alloxan administration. There were still gaps in the histologic outcome possibly due to short experimental time. From Figure 3, we could see that the Langerhans islet condition in extract groups were parallel with the administered dose of the extract. The higher the dose, the fuller the Langerhans islet. From the animal model of insulin deficiency, it could be concluded that the water extract of $M$. calabura leaves at dose of $400 \mathrm{mg} / \mathrm{Kg}$ bw had antidiabetic activity, with the mechanism of regenerating pancreatic islet cells. In this study it was thought that antioxidant activity of the $M$. calabura leaves contribute to disrupt the diabetogenic action of the alloxan.

\section{In vivo Antidiabetic Evaluation of $M$. calabura Leaves Extract in Insulin Resistance Animal Model}

Table 2 showed that lipid emulsion administration with a dose of $0.42 \mathrm{~mL} / 20$ grams bw for 2 weeks could affect the $\mathrm{K}_{\text {ITT }}$ value. The induced group of mice experienced a significant decrease in $\mathrm{K}_{\text {ITT }}$ compared with the negative control group. Lower $\mathrm{K}_{\text {ITT }}$ indicates lower insulin sensitivity. This data was supported by another study that showed lipid administration could induce insulin resistance.(19)

After 2 weeks metformin or extract administration, the $\mathrm{K}_{\text {ITT }}$ was also measured. The result showed that metformin and extract administration could increase the $\mathrm{K}_{\text {ITT }}$ value. We could see that the $\mathrm{K}_{\text {ITT }}$ value in the group given the extract was parallel to the given dose. The higher the dose given, the higher $\mathrm{K}_{\text {ITT }}$ value produced. However, the groups that showed significantly different $\mathrm{K}_{\mathrm{ITT}}$ values compared with the positive control group were the metformin group, the extract group with dose of 200 and $400 \mathrm{mg} / \mathrm{Kg}$ bw. But the group that had activity comparable to metformin as a standard drug was the extract group at dose of $400 \mathrm{mg} /$ $\mathrm{Kg}$ bw. These two groups showed no significant difference statistically. From this experiment, it was concluded that M. calabura leaves water extract could improve the insulin sensitivity in insulin resistance animal model.

Based on phytochemical screening, it was known that $M$. calabura leaf extract contained flavonoid, tannins, triterpenoids, steroids and polyphenols compounds. Flavonoids were thought to decrease blood glucose levels by enhancing insulin secretion, reducing apoptosis and promoting proliferation of pancreatic $\beta$-cells, reducing insulin resistance, inflammation and oxidative stress in muscle and promoting translocation of Glucose transporter 
type 4 (GLUT4) via phosphatidylinositol-3-kinase (PI3K)/ Akt and AMP-activated protein kinase (AMPK) pathways.(26)

The limitation of this study was the absence of measured insulin levels, so we could not determine whether there was a condition of hyperinsulinemia. Moreover, pancreatic staining performed only allowed qualitative histologic observation and could not specify the number of pancreatic $\beta$ cells.

\section{Conclusion}

The conclusion from this experiment was that M. calabura leaves water extract with dose of $400 \mathrm{mg} / \mathrm{Kg}$ bw had the antidiabetic activity with mechanisms to increase insulin secretion, regenerate pancreatic $\beta$ cells, and increase insulin sensitivity.

\section{Acknowledgment}

Authors would like to thank the Research and Community Services Center, Bandung School of Pharmacy, Bandung, Indonesia, for fully supported this research.

\section{References}

1. American Diabetes Association. Classification and diagnosis of diabetes. Diabetes Care. 2015; 38 (Suppl.1): S8-16.

2. DiPiro JT, Wells BG, Schwinghammer TL, DiPiro CV. Pharmacotherapy Handbook. 7th edition. New York: McGraw-Hill; 2009.

3. Shanik MH, Xu Y, Skrha J, Dankner R, Zick Y, Roth J. Insulin resistance and hiperinsulinemia. Diabetes Care. 2008; 31 (Suppl.2): S262-8.

4. International Diabetes Federation (IDF). IDF Diabetes Atlas. 6th Edition. Brussels: International Diabetes Federation; 2013

5. Badan Penelitian dan Pengembangan Kesehatan Kementrian Kesehatan Republik Indonesia. Riset Kesehatan Dasar (RISKESDAS) Tahun 2007. Jakarta: Kementrian Kesehatan RI; 2007.

6. Badan Penelitian dan Pengembangan Kesehatan Kementrian Kesehatan Republik Indonesia. Riset Kesehatan Dasar (RISKESDAS) Tahun 2013. Jakarta: Kementrian Kesehatan RI; 2013.
7. Riaz S. Diabetes mellitus. Sci Res Essays. 2009; 4: 367-73.

8. Katzung BG, Masters SB, Trevor AJ. Basic and Clinical Pharmacology. 12th edition. New York: McGraw-Hill Medical; 2012.

9. Prameswari OM, Widjarnako SB. Uji efek ekstrak air daun pandan wangi terhadap penurunan kadar glukosa darah dan hispatologi tikus diabetes mellitus. Jurnal Pangan dan Agroindustri. 2014; 2: 16-27.

10. Sujono TA, Wahyuni AS. Pengaruh decocta daun lidah buaya (Aloe vera L.) terhadap kadar glukosa darah kelinci yang dibebani glukosa. Jurnal Penelitian Sains dan Teknologi. 2005; 6: 26-34.

11. Zakaria ZA, Mustapha S, Sulaiman MR, Jais AMM, Somchit MN, Abdullah FC. The antinociceptive action of aqueous extract from Muntingia calabura leaves: the role of opioid receptors. Med Princ Pracyt. 2007; 16: 130-6.

12. Youngson R. Antioxidants Vitamins C \& E for Health. London: Sheldon Press; 1998.

13. Tiwari BK, Pandey KB, Abidi AB, Rizvi SI. Markers of oxidative stress during diabetes mellitus. J Biomark. 2013; 2013: 378790. doi: $10.1155 / 2013 / 378790$.

14. Halliwell B, Gutteridge JM. The definition and measurement of antioxidants in biological systems. Free Radic Biol Med. 1995; 18: 125-6.

15. Squadriato GL, Peyor WA. Oxidative chemistry of nitric oxide: the roles of superoxide, peroxynitrite and carbon dioxide. Free Radical Bio Med. 1998; 25: 392-403.

16. Aruna SM, Bodke YD, Chandrashekar A. Antioxidant and in vivo anti-hyperglycemic activity of Muntingia calabura leaves extracts. Der Pharmacia Lettre. 2013; 5: 427-35.

17. Sukandar EY, Elfahmi, Nurdewi. Pengaruh pemberian ekstrak air daun jati belanda (guazuma ulmifolia lamk.) terhadap kadar lipid darah pada tikus jantan. Jurnal Kedokteran Maranatha. 2009; 8: 102-12.

18. Sukandar EY, Sukrasno, Fitri MA. Aktivitas antidiabetika ekstrak etanol herba sambiloto (Andrographis paniculata Nees (Acanthaceae)). J Mat Sains. 2001; 6: 13-20.

19. Ai J, Wang N, Yang M, Du ZM, Zhang YC, Yang BF. Development of wistar rat model of insulin resistance. World J Gastroenterol. 2005; 11: 3675-9.

20. Lian JH, Xiang YQ, Guo L, Hu WR, Gong BQ. The use of high-fat/ carbohydrate diet-fed and streptozotocin-treated mice as a suitable animal model of type 2 diabetes mellitus. Scand J Lab Anim Sci. 2007; 34: 21-9.

21. Etuk EU. Animals models for studying diabetes mellitus. Agric Biol J N Am. 2010; 1: 130-4.

22. Dhanesha N, Joharapurkar A, Shah G, Dhote V, Kshirsagar S, Bahekar R, et al. Exendin-4 ameliorates diabetic symptoms through activation of glucokinase. J Diabetes. 2012; 4: 369-77.

23. Dunn JS, Sheehan HL, Mclethie NGB. Necrosis of islets of langerhans produced experimentally. Lancet. 1943; 1: 484-7.

24. Szkudelski T. The mechanism of alloxan and streptozotocin action in B cells of the rat pancreas. Physiol Res. 2001; 50: 536-46.

25. Lenzen $\mathrm{S}$. The mechanisms of alloxan and streptozotocin-induced diabetes. Diabetologia. 2008; 51: 216-26.

26. Vinayagam $\mathrm{R}, \mathrm{Xu} \mathrm{B}$. Antidiabetic properties of dietary flavonoids: a cellular mechanism review. Nutr Metab. 2015; 12: 60. doi: 10.1186/ s12986-015-0057-7. 